Article

\title{
Direct Electrochemistry of Hemoglobin Immobilized on a Functionalized Multi-Walled Carbon Nanotubes and Gold Nanoparticles Nanocomplex-Modified Glassy Carbon Electrode
}

\author{
Jun Hong ${ }^{1}{ }^{*}$, Ying-Xue Zhao ${ }^{1}$, Bao-Lin Xiao ${ }^{1}$, Ali Akbar Moosavi-Movahedi ${ }^{2, *}$, \\ Hedayatollah Ghourchian $^{2}$ and Nader Sheibani ${ }^{3}$
}

1 School of Life Sciences, Henan University, JinMing Road, Kaifeng 475000, China; E-Mails: 66yingxue@163.com (Y.-X.Z.); arixxl@163.com (B.-L.X.)

2 Institute of Biochemistry and Biophysics, University of Tehran, Enquelab Avenue, P.O. Box 13145-1384, Tehran, Iran; E-Mail: hadi@ibb.ut.ac.ir

3 Department of Ophthalmology and Visual Sciences, University of Wisconsin, 600 Highland Avenue, K6/456 CSC, Madison, WI 53792-4673, USA; E-Mail: nsheibanikar@wisc.edu

* Authors to whom correspondence should be addressed; E-Mails: hongjun@ @enu.edu.cn (J.H.); moosavi@ibb.ut.ac.ir (A.A.M.-M.); Tel.: +86-137-8116-1597 (J.H.); Fax: +86-378-388-6258 (J.H.); Tel.: +98-21-640-3957 (A.A.M.-M.); Fax: +98-21-640-4680 (A.A.M.-M.).

Received: 13 May 2013; in revised form: 17 June 2013 / Accepted: 30 June 2013 / Published: 5 July 2013

Abstract: Direct electron transfer of hemoglobin $(\mathrm{Hb})$ was realized by immobilizing
$\mathrm{Hb}$ on a carboxyl functionalized multi-walled carbon nanotubes (FMWCNTs) and gold
nanoparticles (AuNPs) nanocomplex-modified glassy carbon electrode. The ultraviolet-
visible absorption spectrometry (UV-Vis), transmission electron microscopy (TEM) and
Fourier transform infrared (FTIR) methods were utilized for additional characterization of
the AuNPs and FMWCNTs. The cyclic voltammogram of the modified electrode has a pair
of well-defined quasi-reversible redox peaks with a formal potential of $-0.270 \pm 0.002 \mathrm{~V}$
( $v s . \mathrm{Ag} / \mathrm{AgCl}$ ) at a scan rate of $0.05 \mathrm{~V} / \mathrm{s}$. The heterogeneous electron transfer constant $(\mathrm{ks})$
was evaluated to be $4.0 \pm 0.2 \mathrm{~s}^{-1}$. The average surface concentration of electro-active $\mathrm{Hb}$
on the surface of the modified glassy carbon electrode was calculated to be
$6.8 \pm 0.3 \times 10^{-10}$ mol $\mathrm{cm}^{-2}$. The cathodic peak current of the modified electrode increased
linearly with increasing concentration of hydrogen peroxide (from $0.05 \mathrm{nM}$ to $1 \mathrm{nM}$ ) with a
detection limit of $0.05 \pm 0.01 \mathrm{nM}$. The apparent Michaelis-Menten constant $\left(\mathrm{K}_{\mathrm{m}}{ }^{\text {app }}\right.$ ) was 
calculated to be $0.85 \pm 0.1 \mathrm{nM}$. Thus, the modified electrode could be applied as a third generation biosensor with high sensitivity, long-term stability and low detection limit.

Keywords: hemoglobin; direct electrochemistry; functionalized multi-walled carbon nanotubes; gold nanoparticles; nanocomplex

\section{Introduction}

Direct electrochemistry of redox proteins immobilized on different electrodes has recently attracted great attention. These methods can provide a suitable model for understanding the electron transfer mechanisms in biological systems and to establish a foundation for fabrication of electrochemical biosensors and devices [1-4]. Successful approaches have included cast films of redox proteins with different materials and membranes [5-23]. Achieving direct electron transfer between redox proteins or enzymes and electrodes simplifies these devices, which has a great significance in preparing the third generation of biosensors [24].

Hemoglobin $(\mathrm{Hb})$ is an oxygen carrier and as a pro-oxidant takes part in complex redox processes in the blood. This protein consists of two alpha and two beta subunits with a molecular weight of about 67,000 and each subunit has one peptide chain and one protoheme [25-27]. Hb structure is similar to the peroxidases and can catalyze the reduction of hydrogen peroxide. [28,29]. Direct electron transfer of $\mathrm{Hb}$ immobilized on various electrode materials has become popular. In addition, the structure of $\mathrm{Hb}$ is known and can be used as a model to explain the relationship between the protein structure and function and to construct new functional biosensors without mediators [13,30-32].

Carbon nanotubes are widely used for the fabrication of electrochemical biosensors, because of their special structure and properties such as high surface area, which makes them a suitable material to transfer electrons [33-35]. Gold nanoparticles are one of the most stable metal nanoparticles, and have been widely applied in analytical chemistry and electrochemistry, because of their novel optical, electrical and catalytic properties and favorable biocompatibility [36,37]. Each type of nano-material has its own physical and chemical characteristics, which makes the design and preparation of biosensors based on only one type of nanomaterial laborious. Thus, the use of composites from several type of materials could be preferable [38]. Recently, several nano materials, including carbon nanotubes and nanoparticles of $\mathrm{Au}, \mathrm{Ag}, \mathrm{TiO}_{2}, \mathrm{Fe}_{3} \mathrm{O}_{4}$ or $\mathrm{MnO}_{2}$, have been applied in electrochemical studies of hemoglobin and other redox proteins [39]. Immoblization of redox proteins on nanocomplexes is a new way to realize their direct electrochemistry.

In our previous study, a nanocomplex consisting of carboxylic acid functionalized multi-walled carbon nanotubes (FMWCNTs) and gold nanoparticles (AuPNs) was modified on a glassy carbon (GC) electrode, and applied to analysis the electrochemical properties of catalase [40] and heme-containing artificial peroxidase [41].

In the present study, direct electron transfer of $\mathrm{Hb}$ was realized when it was immobilized on the nanocomplex-modified glassy carbon (GC) electrode. Thus, this electrode could be used as a high sensitivity hydrogen peroxide $\left(\mathrm{H}_{2} \mathrm{O}_{2}\right)$ biosensor. 


\section{Experimental Section}

\subsection{Chemicals}

$\mathrm{Hb}$ from bovine erothrocyte, L-cysteine (Cys), $\mathrm{NF}(5 \%), \mathrm{HAuCl}_{4}$ and sodium citrate were from Sigma (Saint Louis, MO, USA) and used without further purification. Multi-wall carbon nanotubes (MWCNTs), prepared by chemical vapor deposition, were purchased from Shenzhen Nanotech Port Ltd. Co. (Shenzhen, China). Hydrogen peroxide, sodium dihydrogen phosphate $\left(\mathrm{NaH}_{2} \mathrm{PO}_{4}\right)$ and disodium hydrogen phosphate $\left(\mathrm{Na}_{2} \mathrm{HPO}_{4}\right)$ were obtained from Shanghai Chemicals Company (Shanghai, China). All solutions were prepared in double-distilled deionized water. The stock solutions of hydrogen peroxide $\left(\mathrm{H}_{2} \mathrm{O}_{2}\right)$ were prepared by appropriate dilutions of $30 \%(\mathrm{v} / \mathrm{v}) \mathrm{H}_{2} \mathrm{O}_{2}$ in deionized water. All other chemicals were of analytical grade and used without further purification.

\subsection{Preparation of Gold Nanoparticles (AuNPs)}

AuNPs were prepared as previously reported in the literature [42-44]. Briefly, $0.01 \% \mathrm{HAuCl}_{4}$ solution was heated, then $0.02 \mathrm{M}$ sodium citrate solution was dropped quickly into the hot $\mathrm{HAuCl}_{4}$ solution while agitating vigorously. At first, the color of solution changed from light yellow to grey, then to black and gradually to wine red color without further change. At this stage, the color no longer changed, the heating was stopped, and the solution mixture was continuously agitated until it was cooled to room temperature. The prepared gold colloidal nanoparticles (AuNPs) were stored in dark at $4{ }^{\circ} \mathrm{C}$.

\subsection{Preparation of Functional Multi-Walled Carbon Nanotubes (FMWCNTs)}

MWCNTs were functionalized according to published methods [23]. Briefly, purified MWCNTs were treated with a concentrated mixture of $\mathrm{H}_{2} \mathrm{SO}_{4}$ and $\mathrm{HNO}_{3}(\mathrm{v} / \mathrm{v}=1 / 3)$ under supersonic bath condition (KQ-100B Supersonic Cleaner, Kunshan Shumei, Kunshan, China ) for $4 \mathrm{~h}$ at $80{ }^{\circ} \mathrm{C}$ to introduce carboxyl groups on their surface. The solution $\mathrm{pH}$ was then adjusted to 7 with $1 \mathrm{M} \mathrm{NaOH}$ solution, centrifuged and washed with water three times. The obtained MWCNTs-COOH (FMWCNTs) were dried at room temperature.

\subsection{Preparation of Functional Membrane Modified Glassy Carbon (GC) Electrode}

The preparation of the GC electrode was as previously described [45-49]. Prior to coating, the GC electrode was mechanically polished twice with alumina (particle sizes $1.00,0.30$ and $0.05 \mu \mathrm{m}$, respectively) to a mirror finish. The electrode was then treated electrochemically in $0.2 \mathrm{M}$ sulfuric acid, cycling between -1.0 and $+0.5 \mathrm{~V}(\mathrm{vs} . \mathrm{Ag} / \mathrm{AgCl})$ at a sweep rate of $0.1 \mathrm{~V} / \mathrm{s}$ for approximately 10 min. Thereafter, the working electrode was placed in a $50 \mathrm{mM}$ PBS (pH 7.0), and an anodic potential of $1.70 \mathrm{~V}$ ( $v s . \mathrm{Ag} / \mathrm{AgCl}$ ) was applied for 3-5 min. After the electrode was washed, the AuNPs (negative charged) were electro-deposited on a cleaned bare GC electrode in the range of 0.0 to1.1 V 25 cycles at a scan rate of $0.1 \mathrm{~V} / \mathrm{s}$ [50]. The GC electrode was then dipped in $1.0 \mathrm{mM}$ L-cysteine (Cys) for $30 \mathrm{~min}$, washed with water, $3 \mu \mathrm{L}$ of FMWCNTs $(2 \mathrm{mg} / \mathrm{mL})$ was dropped onto the surface of the electrode, and dried at room temperature. The electrode was dipped in a Hb solution $(80 \mu \mathrm{M})$ for $24 \mathrm{~h}$ 
at $4{ }^{\circ} \mathrm{C}$, and for protection, $2 \mu \mathrm{L}$ Nafion (NF, 5\%) was dropped on the electrode surface. The preparation process of functional membrane modified glassy carbon (GC) electrode was also shown in Figure 1.

Figure 1. Preparation process of functional membrane modified glassy carbon (GC) electrode.

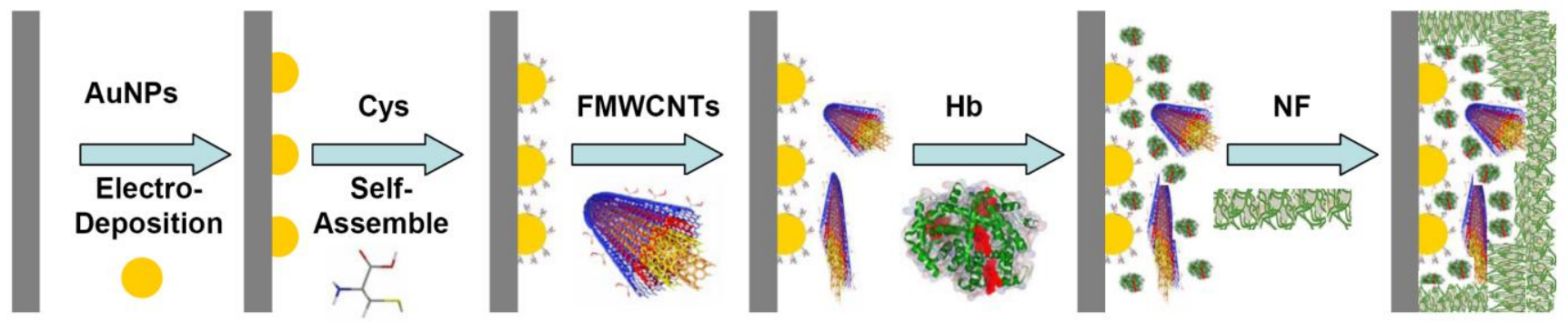

\subsection{Apparatus and Measurements}

Electrochemical studies were carried out in a conventional three-electrode cell powered by an electrochemical system comprising of CHI650C (CHI Instruments, Austin, TX, USA). $\mathrm{An} \mathrm{Ag} / \mathrm{AgCl}$-saturated $\mathrm{KCl}$, a Pt wire and a $\mathrm{GC}$ electrode of $3 \mathrm{~mm}$ diameter (CHI Instruments) were used as the reference, counter and working electrodes, respectively. All of the potentials in this article were with respect to $\mathrm{Ag} / \mathrm{AgCl}$. The electrochemical measurements were carried out in $\mathrm{N}_{2}$-saturated $0.05 \mathrm{M}$ sodium phosphate buffer solution (PBS) at $\mathrm{pH} 7.0,20^{\circ} \mathrm{C}$. Electron microscopic images (TEM) of FMWCNT and AuNPs were obtained using a JEM-1400 (JEOL, Musashino, Japan). Fourier transform infrared (FTIR) spectra of FMWCNTs by $\mathrm{KBr}$ pellets were cellected in the range of 1,000-3,500 $\mathrm{cm}^{-1}$ on a FTIR 4300 (Shimadzu, city, Japan) spectrometer at room temperature. UV-vis absorption spectra of the AuNPs were collected using a TU-1901 spectrophotometer (Beijing Purkinje General Instrument Company, Beijing, China), with $1 \mathrm{~cm}$ path length cells equipped with a thermostat holder and an external temperature controller (Shanghai Hengping Instrument Company, Shanghai, China) at $25 \pm 0.1^{\circ} \mathrm{C}$.

\section{Results and Discussion}

\subsection{Characteristics of the Nanomaterials}

The AuPNs and FMWCNTs were characterized by TEM. $3 \mu \mathrm{L}$ of AuPNs $(0.254 \mathrm{mM})$ or FMWCNTs ( $3 \mathrm{mg} / \mathrm{mL}$ ) was dropped onto the surface of fomvar/carbon coated grids (300 mesh), dried and then viewed by TEM operating at $80 \mathrm{kV}$ [40], respectively. UV-vis spectroscopy of the prepared AuNPs exhibited a maximum absorption at $522 \mathrm{~nm}$. The mean size of the AuNPs was then determined to be $18.4 \pm 1.1 \mathrm{~nm}[40,51]$. The FTIR spectrum of FMWCNTs shows the characteristic peaks at $1,709,1,172$, and $3,402 \mathrm{~cm}^{-1}$ correspond to the $\mathrm{C}=\mathrm{O}, \mathrm{C}-\mathrm{O}$ and $\mathrm{O}-\mathrm{H}$ stretching vibration of the carboxyl group [52-54], respectively, which indicates that carboxyl groups were modified on the MWCNTs (data not shown). 


\subsection{Electrochemical Studies}

Figure 2(A) presents the cyclic voltammograms (CVs) of: (a) bare electrode; (b) NF/Hb/GC electrode; (c) NF/FMWCNTs/Cys/AuNPs /GC electrode; (d) NF/Hb/FMWCNTs/GC electrode; and (e) $\mathrm{NF} / \mathrm{Hb} / \mathrm{FMWCNTs} / \mathrm{Cys} / \mathrm{AuNPs} / \mathrm{GC}$ electrode at a scan rate of $0.05 \mathrm{~V} / \mathrm{s}$. It can be seen that either (d) or (e) show a well-defined redox wave. The electrode (e) had a stronger redox peak current than that of (d), and the AuPNs could help to significantly increase the redox peaks. Moreover, cathodic and anodic peak potentials were $-0.309 \mathrm{~V}$ and $-0.231 \mathrm{~V}$ (vs. $\mathrm{Ag} / \mathrm{AgCl})$, respectively. Thus, the formal potential $\left(\mathrm{E}^{\circ \prime}=\left(\mathrm{E}_{\mathrm{pa}}+\mathrm{E}_{\mathrm{pc}}\right) / 2\right)$ of the electrode $(\mathrm{e})$ was $-0.270 \pm 0.002 \mathrm{~V}$ (vs. $\left.\mathrm{Ag} / \mathrm{AgCl}\right)$. This value is consistent with the $\mathrm{E}^{\mathrm{o}}$ obtained for an $\mathrm{Hb} / \mathrm{PLGA} / \mathrm{ILs} / \mathrm{GC}$ electrode $(-0.318 \mathrm{~V}$ vs. SCE) [21], an $\mathrm{Hb} / \mathrm{BMS} / \mathrm{CS} / \mathrm{GC}$ electrode $(-0.32 \mathrm{~V}$ vs. $\mathrm{Ag} / \mathrm{AgCl})$ [55], or an $\mathrm{Hb} / \mathrm{Chit}-[\mathrm{bmim}] \mathrm{PF}_{6}-\mathrm{TiO}_{2}-\mathrm{Gr} / \mathrm{GC}$ electrode $\left(-0.206 \mathrm{~V}\right.$ vs. SCE) [17], which is the characteristics of the $\mathrm{Hb}$ heme $\mathrm{Fe}^{(\mathrm{III})} / \mathrm{Fe}^{(\mathrm{II})}$ redox couple. It is notable that the positive potential for the electrode facilitated the electrode reaction (Equation (1)) and led to a more efficient bio-catalytic reduction [46,47,49]:

$$
k_{s}=A e^{-\Delta G / R T} e^{-\alpha n F E} .
$$

The separation between the anodic and cathodic peak potential $\left(\mathrm{E}_{\mathrm{p}}=\mathrm{E}_{\mathrm{pa}}-\mathrm{E}_{\mathrm{pc}}=78 \mathrm{mV}\right)$, and the current ratio of the anodic peak current to the cathodic one $\left(\mathrm{I}_{\mathrm{pa}} / \mathrm{I}_{\mathrm{pc}} \approx 1\right)$, indicate that the electrochemical process of the modified GC electrode (e) is quasi-reversible [46,47]. Thus, AuNPs can greatly improve the redox current-modified electrode and facilitate a fast direct electron transfer of $\mathrm{Hb}$ entrapped in the composite film. In addition, it is worth noting that there was a pair of unstable redox peaks for curves at site 1 and 2, which should be due to Cys-modified Au, and this redox peak would disappear gradually while the electrode was working. CVs of NF/Hb/FMWCNTs/Cys/AuNPs/GC electrode in $50 \mathrm{mM}$ PBS (pH 7.0) at various scan rates are shown in Figure 2(B). The peak currents increased with increasing the scan rate $(v)$ and were linearly proportional to $v$ (Figure $2 \mathrm{C})\left(\right.$ not $v^{1 / 2}$ ). The linear regression equations for cathodic $\left(\mathrm{I}_{\mathrm{pc}}\right)$ and anodic peak $\left(\mathrm{I}_{\mathrm{pa}}\right)$ currents are: $\mathrm{I}_{\mathrm{pc}}=12.65 \mathrm{v}+0.14$ and $\mathrm{I}_{\mathrm{pa}}=-12.45 \mathrm{v}-0.13$, with the correlation coefficients of 0.9981 and 0.9977 , respectively. The CVs remained essentially unchanged on consecutive potential cycling, indicating that modified electrode is stably confined on the glassy carbon electrode. Figure 2(D) shows the relationship between the peak potential $\left(\mathrm{E}_{\mathrm{p}}\right)$ and the natural logarithm of scan rate $(\ln v)$ for the modified electrode. In the range from 1.2 to $4 \mathrm{~V} / \mathrm{s}$, the cathodic peak potential $\left(\mathrm{E}_{\mathrm{pc}}\right)$ changed linearly $v s$. $\ln v$ with a linear regression equation of $\mathrm{E}_{\mathrm{pc}}=-0.0302 \ln (v)-0.324, r=0.991$. According to Laviron's Equation [56]:

$$
E_{p}=E^{\circ}+\frac{R T}{\alpha n F}-\frac{R T}{\alpha n F} \ln v
$$

where $\alpha$ is the cathodic electron transfer coefficient, $\mathrm{n}$ is the number of electrons, $\mathrm{T}$ is the temperature (293 $\mathrm{K}$ here), $\mathrm{R}$ the gas constant $\left(8.314 \mathrm{JK}^{-1} \mathrm{~mol}^{-1}\right)$ and $\mathrm{F}$ the Faraday constant $\left(96,485 \mathrm{C} \mathrm{mol}^{-1}\right)$, respectively. $\mathrm{RT} / \alpha \mathrm{nF}$ was 0.0302 here, then, $\alpha$ could be calculated to be 0.55 It could be concluded that $n=1$ and $\alpha=0.55 \pm 0.05$ [57]. The $n=1$ can be also obtained from the width of the peak at mid- height with a low scan rate. Thus, the redox reaction between $\mathrm{Hb}$ and the glassy carbon electrode is a single electron transfer process. 
Figure 2. (A) CVs of different modified electrodes (from inner to outer): (a) Bare GC electrode; (b)NF/Hb/GC; (c) NF/FMWCNTs/Cys/AuNPs/GC; (d) NF/Hb/FMWCNTs/GC; (e) NF/Hb/FMWCNTs/Cys/AuNPs/GC. The experiments were carried out in $0.05 \mathrm{M} \mathrm{PBS}$ (pH7.0) at a scan rate of $0.05 \mathrm{~V} / \mathrm{s}$. (B) $\mathrm{CVs}$ of NF/Hb/FMWCNTs/Cys/AuNPs/GC electrode in 0.05 M PBS ( $\mathrm{pH} 7.0$ ) at various scan rates (from inner to outer): 0.02, 0.04, $0.06,0.08,0.1,0.12,0.14,0.16,0.18 \ldots 4 \mathrm{~V} / \mathrm{s}$, respectively; (C) Plot of peck current $\mathrm{I}_{\mathrm{p}} v s$. scan rate $v ;(D)$ Plot of peak potential $\mathrm{E}_{\mathrm{p}} v s . \ln (v)$.
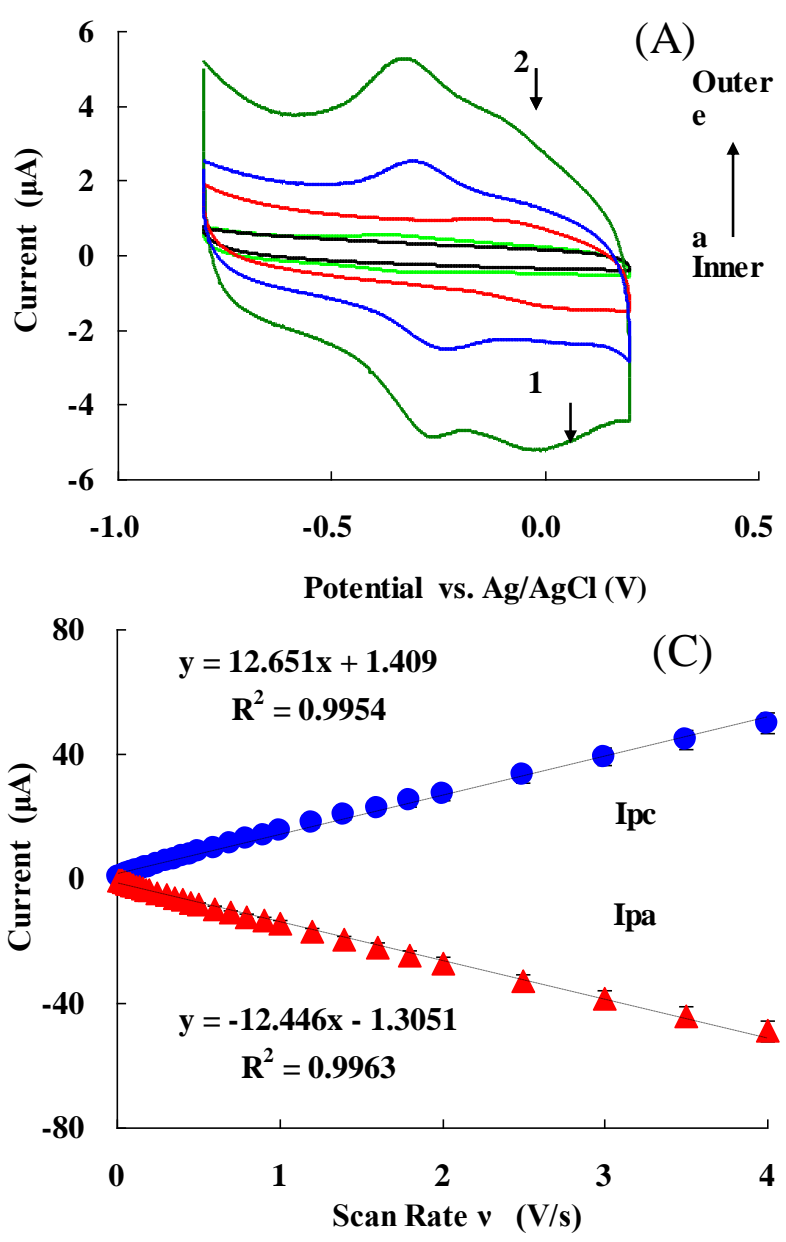

(B)

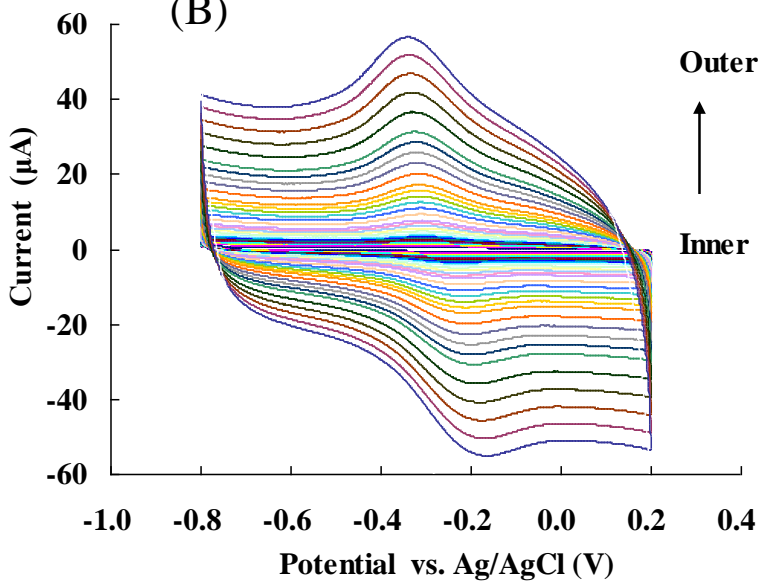

(D)

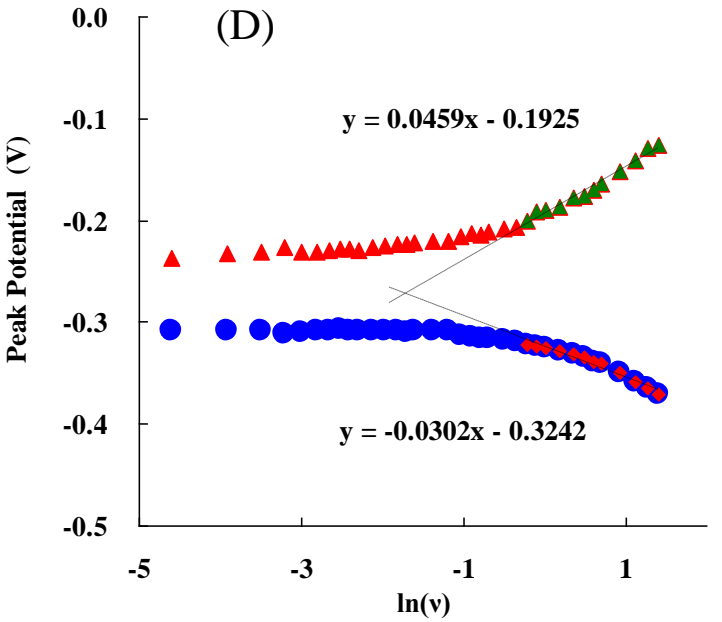

The value of the apparent heterogeneous electron transfer rate constant $\mathrm{k}_{\mathrm{s}}$ could be calculated using the following equation based on Laviron's Equation [58]:

$$
\ln k_{s}=\alpha \ln (1-\alpha)+(1-\alpha) \ln \alpha-\ln \left(\frac{R T}{n F v}\right)-\alpha(1-\alpha) \frac{n F \Delta E_{p}}{R T} .
$$

Then, $\mathrm{k}_{\mathrm{s}}$ was calculated to be $4.0 \pm 0.2 \mathrm{~s}^{-1}$. This value was higher than the most reported $\mathrm{k}_{\mathrm{s}}$ values of $\mathrm{Hb}$ immobilized on GC electrodes [5,9,10,17,23], due to the high specific surface area and good biocompatibility of the nano-complex.

The average surface concentration $(\Gamma)$ of electro-active sites (heme groups) of $\mathrm{Hb}$ on the surface of glassy carbon electrode could be estimated based on the slope of $\mathrm{I}_{\mathrm{p}} v s . v$ (Equation (4)) [59]:

$$
I_{p}=\frac{n^{2} F^{2} A \Gamma v}{4 R T} .
$$


The value of $\Gamma$ was calculated to be $6.8 \pm 0.3 \times 10^{-10} \mathrm{~mol} \cdot \mathrm{cm}^{-2}$, which is higher than the $\Gamma$ value of monolayer of $\mathrm{Hb} 1.89 \times 10^{-11} \mathrm{~mol} \cdot \mathrm{cm}^{-2}[60,61]$. This high surface concentration can be attributed to the AuNPs and FMWCNTs nanocomplex. The larger surface area and good biocompatibility of the nanocomplex may be helpful for more efficient $\mathrm{Hb}$ entrapped in the nanocomplex membrane and provides more activity sites to take part in the electron transfer process (see also Figure 1).

\section{3. $p H$ Effect}

Figure 3(A) represents $\mathrm{CVs}$ of the modified electrode in $50 \mathrm{mM}$ PBS at various $\mathrm{pH}$ values. An increase in $\mathrm{pH}$ of the solution from 5.0 to 8.0 led to a negative shift in both reduction and oxidation peak potentials. Figure 3(B) shows that the cathodic peak's current increased with $\mathrm{pH}$ changes from 5.0 to 7.0, and then decreased when the $\mathrm{pH}$ was greater than 7.0. The maximum cathodic current was obtained at $\mathrm{pH}$ 7.0. Figure 3(C) shows that the formal potential of the electrode is $\mathrm{pH}$ dependent. These results indicated that the slope was $28.1 \pm 0.4 \mathrm{mV} / \mathrm{pH}$ over a $\mathrm{pH}$ range of 5.0 to 8.0. This value was much smaller than the ideal Nernst's value of $59.2 \mathrm{mV} / \mathrm{pH}$ for a one electron and one proton process [59]. The reason might be the biocompatible micro-environment provided by NF. This makes the electrode more stable to $\mathrm{pH}$ changes [45-48], influences the protonation state of trans ligands to the heme iron and amino acids around the heme, or the protonation of the water molecules coordinated to the central iron [62].

Figure 3. (A) $\mathrm{CVs}$ of $\mathrm{NF} / \mathrm{Hb} / \mathrm{FMWCNTs} / \mathrm{Cys} / \mathrm{AuNPs} / \mathrm{GC}$ electrode in $0.05 \mathrm{M} \mathrm{PBS}$ at different pH values: (a) 5.0, (b) 6.0, (c) 7.0, and (d) 8.0, respectively; (B) plot of $\mathrm{I}_{\mathrm{pc}} v s . \mathrm{pH}$ value; (C) Plot of $\mathrm{E}^{\mathrm{o}}$ vs. $\mathrm{pH}$ value.

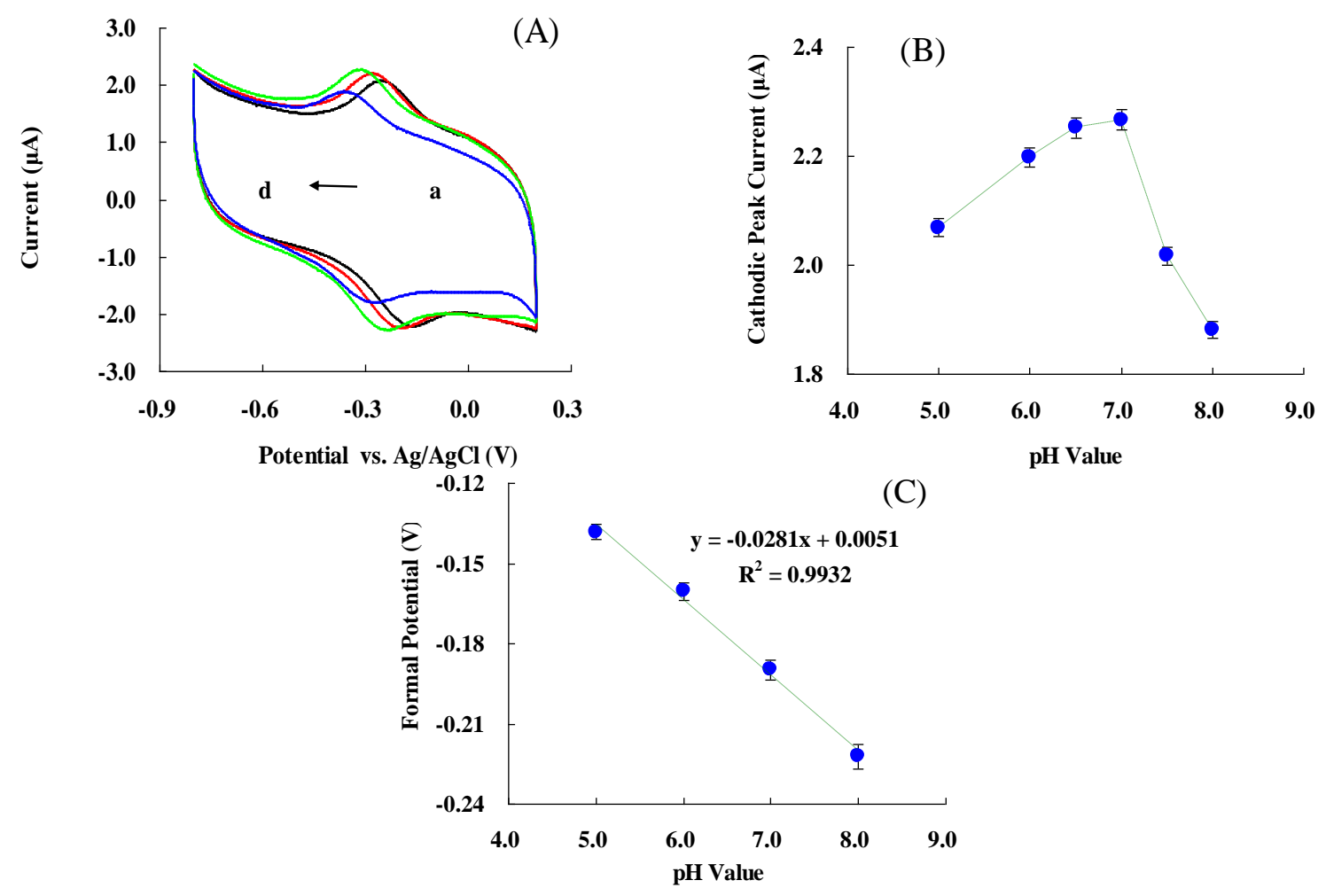




\subsection{Optimum Monitoring Potential}

Figure 4(A) shows the linear sweep voltammograms (LSVs) of NF/Hb/FMWCNTs/Cys/AuNPs/GC electrode in the absence (a) and presence of $\mathrm{H}_{2} \mathrm{O}_{2}$ and with $0.1,0.13,0.16,0.2 \mathrm{mM} \mathrm{H}_{2} \mathrm{O}_{2}$ (b-e). The cathodic peak current increased with increased concentration of $\mathrm{H}_{2} \mathrm{O}_{2}$. Thus, the electrode is sensitive to the tested concentrations of the chosen substrate and used as a biosensor of $\mathrm{H}_{2} \mathrm{O}_{2}$. In addition, the $\Delta \mathrm{I}$ reached a maximum value for each concentration of $\mathrm{H}_{2} \mathrm{O}_{2}$ at about $-350 \mathrm{mV}$. Hence, the potential of $-350 \mathrm{mV}$ (vs. $\mathrm{Ag} / \mathrm{AgCl}$ ) was selected as the optimized monitoring potential throughout this study.

It is worth noting that either Cys/AuNPs/GC (Figure 4(B)) or NF/Cys/AuNPs/GC (Figure 4(C)) electrodes exhibited an amperometric response to $\mathrm{H}_{2} \mathrm{O}_{2}$ at potentials higher than $-0.6 \mathrm{~V}$ (vs. $\mathrm{Ag} / \mathrm{AgCl}$ ). These results were similar to those reported in the literature [63,64]. However, Figure 4(D) shows that the amperometric response of the NF/Hb/AuNPs/GC electrode toward $\mathrm{H}_{2} \mathrm{O}_{2}$ occurred at an even lower potential $(-400 \mathrm{mV})$ with stronger current intensity. Thus, these results could be attributed to the bioelectro-catalytic behavior of $\mathrm{Hb}$.

Figure 4. LSVs of (A) NF/Hb/FMWCNTs/Cys/AuNPs/GC electrode in the absence or presence of different concentrations of $\mathrm{H}_{2} \mathrm{O}_{2}$ (from curve a to curve e): $0,0.1,0.13,0.16$, $0.20 \mathrm{mM}$, respectively. LSVs of (B) Cys/AuNPs/GC; (C) NF/Cys/AuNPs/GC and (D) $\mathrm{NF} / \mathrm{Hb} / \mathrm{Cys} / \mathrm{AuNPs} / \mathrm{GC}$ electrodes, respectively in the presence of different concentrations of $\mathrm{H}_{2} \mathrm{O}_{2}$ (from a to curve d): 0.1, 0.3, 0.5 and $0.7 \mathrm{mM}$, respectively.
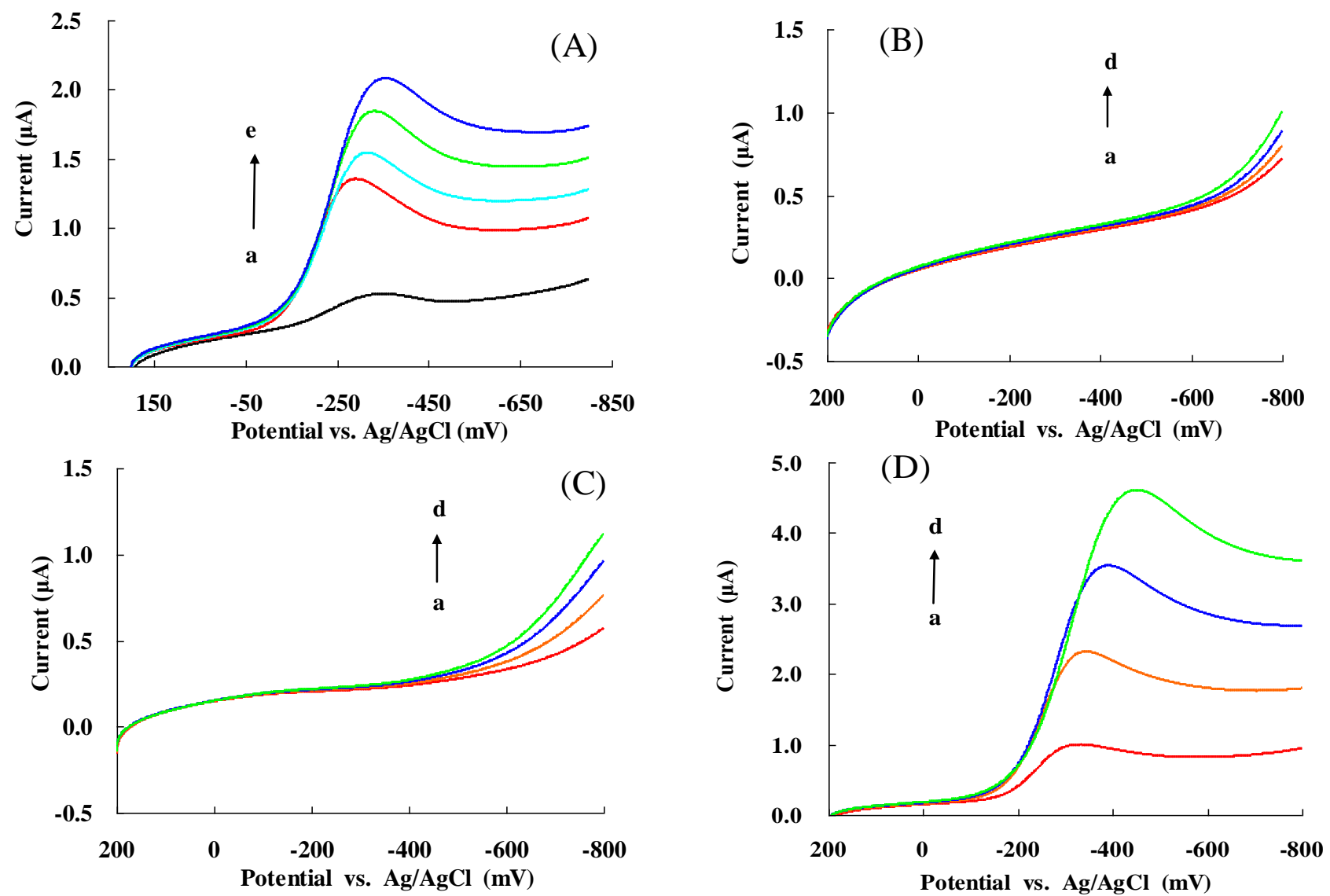


\subsection{Electro-Catalytic Behavior of Modified Electrode and Detection Limit}

Figure 5 presents the current responses of the modified electrode to successive additions of $5 \mu \mathrm{L}$ of $1 \mathrm{nM}$ (a), $10 \mathrm{nM}$ (b) or $20 \mathrm{nM}$ (c) of $\mathrm{H}_{2} \mathrm{O}_{2}$ in $5 \mathrm{~mL}$ of $0.05 \mathrm{M}$ PBS (pH 7.0) at the applied potential of $-0.35 \mathrm{~V}(v s . \mathrm{Ag} / \mathrm{AgCl})$. The inset shows the typical current response for each addition process. Current at state 1 is a steady state $\left(\mathrm{I}_{\mathrm{sa}}\right)$ with no addition, when $\mathrm{H}_{2} \mathrm{O}_{2}$ is added the current increases rapidly and reaches a maximum, state $2\left(\mathrm{I}_{\mathrm{ma}}\right)$. The current then reduces gradually to a steady state, state $3\left(\mathrm{I}_{\mathrm{sb}}\right)$, before the next addition and next maximum current response $\left(\mathrm{I}_{\mathrm{mb}}\right)$, state 4 . Though the amount of maximum response current was great, this state was unsuitable for use, as the change of the maximum current response $\left(\Delta \mathrm{I}=\mathrm{I}_{\mathrm{mb}}-\mathrm{I}_{\mathrm{ma}}\right)$ was not stable for each addition, and was affected by the mainly addition position and diffusion rate of $\mathrm{H}_{2} \mathrm{O}_{2}$. The steady state current response $\left(\Delta \mathrm{I}=\mathrm{I}_{\mathrm{sb}}-\mathrm{I}_{\mathrm{sa}}\right)$ increased when the addition concentration of added $\mathrm{H}_{2} \mathrm{O}_{2}$ was over $10 \mathrm{nM}$ with the final concentration of $\mathrm{H}_{2} \mathrm{O}_{2}(0.01-50 \mathrm{nM}$ ) and a linear range from 0.05 to $1 \mathrm{nM}$ (see also Figure 6(A)).

Figure 5. Amperometirc response of the modified electrode to successive additions of $5 \mu \mathrm{L}$ of $1 \mathrm{nM}(\mathrm{a}), 10 \mathrm{nM}(\mathrm{b})$ or $20 \mathrm{nM}(\mathrm{c}) \mathrm{H}_{2} \mathrm{O}_{2}$ in $5 \mathrm{~mL}$ of $0.05 \mathrm{M}$ PBS, pH 7.0, at the applied potential of $-0.35 \mathrm{~V}$ (vs. $\mathrm{Ag} / \mathrm{AgCl})$. Inset shows the typical current response for each addition process: (1) previous steady state current; (2) maximum response current; (3) steady state current; (4). next maximum response current.

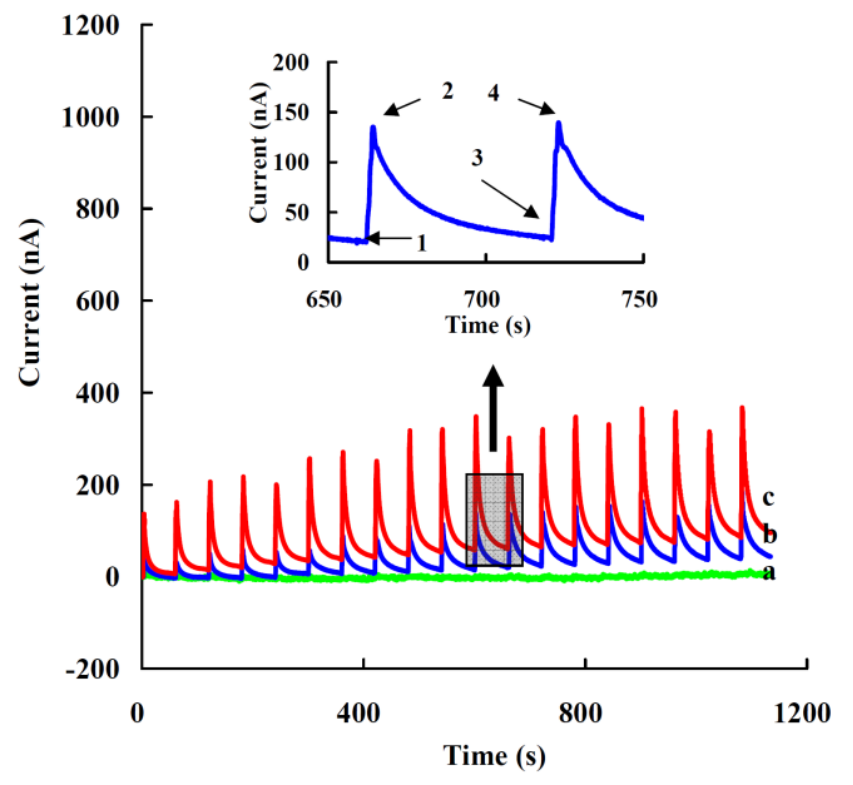

To determine the detection limit (minimum concentration of $\mathrm{H}_{2} \mathrm{O}_{2}$ that could be detected by this method), the steady current $\left(\mathrm{I}_{\mathrm{s}}\right)$ of each addition was measured while the final concentration of $\mathrm{H}_{2} \mathrm{O}_{2}$ $\left(\left[\mathrm{H}_{2} \mathrm{O}_{2}\right]\right.$ ) was increased gradually (Figure 6(B)). The detection limit was determined to be $0.05 \pm 0.01 \mathrm{nM}$ from the cross point of the lines fitted to the linear segments of the $\mathrm{I}_{\mathrm{s}} v s$. $\left[\mathrm{H}_{2} \mathrm{O}_{2}\right][65,66]$, which was lower than the most reported values, e.g., an Hb/GNPs/Hb/MWNT/GC electrode (80 nM) [67] and a $\mathrm{CAT} /[\mathrm{bmim}]\left[\mathrm{PF}_{6}\right] / \mathrm{MWCNTs} / \mathrm{GC}$ electrode $(0.25 \mathrm{nM})[68]$. 
Figure 6. (A) The typical steady current vs. $\left[\mathrm{H}_{2} \mathrm{O}_{2}\right]$ in the process of successive additions of $5 \mu \mathrm{L}$ of $10 \mathrm{nM}(\bullet)$ and $20 \mathrm{nM}(\boldsymbol{\Delta}) \mathrm{H}_{2} \mathrm{O}_{2}$ in $5 \mathrm{~mL}$ of $50 \mathrm{mM}$ PBS (pH 7.0) at the applied potential of $-0.35 \mathrm{~V}$ (vs. $\mathrm{Ag} / \mathrm{AgCl}$ ). (B) The determination of the $\mathrm{H}_{2} \mathrm{O}_{2}$ detection limit for $\mathrm{NF} / \mathrm{Hb} / \mathrm{FMWCNTs} / \mathrm{Cys} / \mathrm{AuNPs} / \mathrm{GC}$ electrode. The detection limit was determined from the cross point of the lines fitted to the linear segments of the steady current Is vs. $\left[\mathrm{H}_{2} \mathrm{O}_{2}\right]$ in the process of successive additions of $5 \mu \mathrm{L}$ of $10 \mathrm{nM} \mathrm{H}_{2} \mathrm{O}_{2}$ in $5 \mathrm{~mL}$ of $50 \mathrm{mM}$ PBS (pH7.0). (C) Lineweaver-Burk plot for $\mathrm{K}_{\mathrm{m}}{ }^{\text {app }}$ determination.
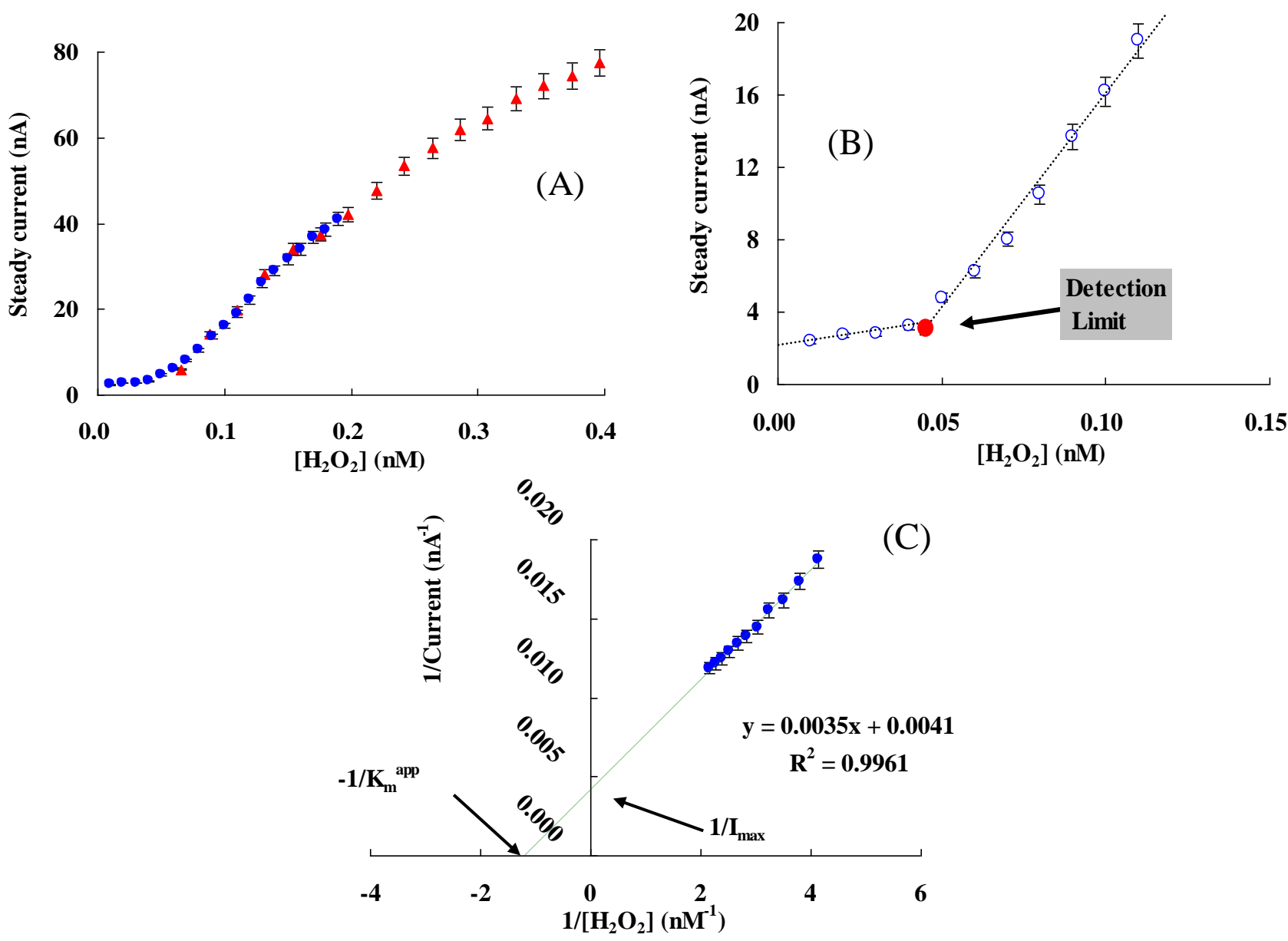

\subsection{Kinetic Parameters}

Overall, the electrode reaction could be supposed to be carried out by two steps [40]:

$$
\begin{gathered}
\text { Step One: } \mathrm{Hb}\left(\mathrm{Fe}^{\mathrm{III}}\right)+\mathrm{e}+\mathrm{H}^{+}=\mathrm{Hb}\left(\mathrm{Fe}^{\mathrm{II}}-\mathrm{H}\right) \\
\text { Step Two: } \mathrm{Hb}\left(\mathrm{Fe}^{\mathrm{II}}-\mathrm{H}\right)+1 / 2 \mathrm{H}_{2} \mathrm{O}_{2} \rightarrow \mathrm{Hb}\left(\mathrm{Fe}^{\mathrm{III}}\right)+\mathrm{H}_{2} \mathrm{O}
\end{gathered}
$$

where, $\mathrm{Hb}\left(\mathrm{Fe}^{\mathrm{III}}\right)$ and $\mathrm{Hb}\left(\mathrm{Fe}^{\mathrm{II}}-\mathrm{H}\right)$ denote the oxidized and reduced forms of the modified $\mathrm{Hb}$, respectively. Initially $\mathrm{Hb}\left(\mathrm{Fe}^{\mathrm{III}}\right)$ undergoes the electron transfer reaction with the electrode resulting in the production of $\mathrm{Hb}\left(\mathrm{Fe}^{\mathrm{II}}-\mathrm{H}\right)$, as shown in Step One, this is an one-electron and one-proton (pH dependent) process. Alternatively, $\mathrm{Hb}\left(\mathrm{Fe}^{\mathrm{II}}-\mathrm{H}\right)$ can be oxidized by $\mathrm{H}_{2} \mathrm{O}_{2}$ in the solution to regenerate $\mathrm{Hb}\left(\mathrm{Fe}^{\mathrm{III}}\right)$ as shown in Step Two. In this catalytic reaction, the peak current kept rising until $\mathrm{Hb}\left(\mathrm{Fe}^{\mathrm{III}}\right)$ was consumed in the Step One and was compensated by its production in Step Two. 
The apparent Michaelis-Menten constant $\mathrm{K}_{\mathrm{m}}{ }^{\text {app }}$ is a reflection of both enzyme affinity and ratio of microscopic kinetic constants. It can be obtained from the electrochemical version of the Linewearver-Burk Equation [13]:

$$
\frac{1}{I_{s s}}=\frac{1}{I_{\max }}+\frac{K_{m}^{a p p}}{I_{\max } c}
$$

where, $c$ is the substrate $\left(\mathrm{H}_{2} \mathrm{O}_{2}\right)$ concentration in the solution $\left(\left[\mathrm{H}_{2} \mathrm{O}_{2}\right]\right.$ here $)$, $\mathrm{I}_{\text {SS }}$ the steady-state current after the addition of substrate, and $\mathrm{I}_{\max }$ is the maximum current measured under saturated substrate conditions. $\mathrm{K}_{\mathrm{m}}{ }^{\text {app }}$ value of the modified electrode was calculated to be $0.85 \pm 0.1 \mathrm{nM}$ (Figure 6(C)), which was much lower than the most reported values, e.g., an HRP-AQ/GC electrode (51 nM) [49], a PLGA/ILs/Hb/GC electrode $(69 \mu \mathrm{M})$ [21], and an $\mathrm{Hb} / \mathrm{Chit}-[\mathrm{bmim}] \mathrm{PF}_{6}-\mathrm{TiO}_{2}-\mathrm{Gr} / \mathrm{GC}$ electrode $(1.245 \mathrm{mM})$ [17] . A low $\mathrm{K}_{\mathrm{m}}{ }^{\text {app }}$ value indicates a strong substrate binding and exhibits a higher affinity of $\mathrm{H}_{2} \mathrm{O}_{2}$ for this modified electrode. FMWCNTs and AuNPs complex system helps to reduce the bridge length between electroactive center (heme group) of $\mathrm{Hb}$ and GC electrode [47], and result in the high sensitivity of the modified electrode to $\mathrm{H}_{2} \mathrm{O}_{2}$ (Table 1).

Table 1. Comparison of electrochemical parameters of $\mathrm{Hb}$ on different modified GC electrodes.

\begin{tabular}{|c|c|c|c|c|c|c|c|}
\hline Modified Electrode & $\mathbf{E}^{\mathbf{o r}}(\mathrm{mV})$ & $\mathbf{k}_{\mathrm{s}}\left(\mathrm{s}^{-1}\right)$ & $\Gamma\left(\mathrm{mol} \cdot \mathrm{cm}^{-2}\right)$ & $\mathbf{K}_{\mathbf{m}}^{\text {app }}$ & Linear Range & $\begin{array}{c}\text { Detection } \\
\text { Limit }\end{array}$ & Ref \\
\hline $\begin{array}{c}\text { NF/Hb/FMWCNTs/ } \\
\text { Cys/AuNPs/GC }\end{array}$ & $-270 \pm 2^{a}$ & $4.0 \pm 0.2$ & $6.8 \pm 0.3 \times 10^{-10}$ & $0.85 \mathrm{nM}$ & $0.05-1 \mathrm{nM}$ & $0.05 \mathrm{nM}$ & This work \\
\hline $\mathrm{Hb} / \mathrm{PdNPs} / \mathrm{GR}-\mathrm{CS} / \mathrm{GC}$ & $-240^{\mathrm{b}}$ & 0.69 & $1.74 \times 10^{-10}$ & $16 \mu \mathrm{M}$ & $2-1100 \mu \mathrm{M}$ & $660 \mathrm{nM}$ & [5] \\
\hline $\mathrm{Hb} / \mathrm{NiO} / \mathrm{GC}$ & $-70^{\mathrm{a}}$ & $5.2 \pm 0.5$ & $1.73 \times 10^{-11}$ & $1370 \mu \mathrm{M}$ & $1-2000 \mu \mathrm{M}$ & $630 \mathrm{nM}$ & [6] \\
\hline NF/Hb/PAM-P123/GC & $-317^{\mathrm{b}}$ & - & $7.64 \times 10^{-11}$ & $36 \mu \mathrm{M}$ & $1-30 \mu \mathrm{M}$ & $400 \mathrm{nM}$ & [7] \\
\hline $\mathrm{Hb} / \mathrm{Gel} / \mathrm{GC}$ & $-380^{\mathrm{b}}$ & - & - & - & $50-1200 \mu \mathrm{M}$ & $3400 \mu \mathrm{M}$ & [8] \\
\hline $\mathrm{Hb} / \mathrm{NGC}-\mathrm{SF} / \mathrm{GC}$ & $-380^{b}$ & 1.98 & - & - & $\begin{array}{l}0.6-1.7 \text { and } \\
2-22 \mathrm{mM}\end{array}$ & - & [9] \\
\hline $\begin{array}{c}\text { Polymer-Hb- } \\
\text { CNTs/GC }\end{array}$ & $-273^{b}$ & 0.90 & $1.1 \times 10^{-10}$ & $140 \mu \mathrm{M}$ & $8-240 \mu \mathrm{M}$ & $4 \mu \mathrm{M}$ & {$[10]$} \\
\hline $\begin{array}{c}\mathrm{Hb} / \mathrm{CS}-[\mathrm{bmim}] \\
\mathrm{PF}_{6}-\mathrm{TiO}_{2}-\mathrm{GR} / \mathrm{GC}\end{array}$ & $-206^{b}$ & $0.73-3.96$ & $3.21 \times 10^{-10}$ & $1245 \mu \mathrm{M}$ & $1-1170 \mu \mathrm{M}$ & $0.3 \mu \mathrm{M}$ & [17] \\
\hline Hb/PLGA/ILs/GC & $-318^{b}$ & $5.02 \pm 0.16$ & $4.74 \times 10^{-10}$ & $69 \mu \mathrm{M}$ & $5-8050 \mu \mathrm{M}$ & $0.237 \mu \mathrm{M}$ & [21] \\
\hline $\mathrm{Hb} / \mathrm{ATP} / \mathrm{GC}$ & $-362^{b}$ & $4.6 \pm 0.65$ & $6.7 \times 10^{-11}$ & $490 \mu \mathrm{M}$ & $5.4-400 \mu \mathrm{M}$ & $2.4 \mu \mathrm{M}$ & {$[22]$} \\
\hline EDC-Hb-CNTs/GC & $-268^{b}$ & $1.02 \pm 0.05$ & $4.7 \times 10^{-9}$ & - & $0.25-140 \mu \mathrm{M}$ & $0.18 \mu \mathrm{M}$ & [23] \\
\hline $\mathrm{Hb} / \mathrm{BMS} / \mathrm{CS} / \mathrm{GC}$ & $-320^{a}$ & - & $9.34 \times 10^{-11}$ & - & $2.5-245 \mu \mathrm{M}$ & $0.83 \mu \mathrm{M}$ & {$[55]$} \\
\hline $\begin{array}{c}\mathrm{Hb} / \mathrm{GNPs} / \mathrm{Hb} / \mathrm{MWNT} / \\
\mathrm{GC}\end{array}$ & $-355^{\mathrm{b}}$ & - & - & $260 \mu \mathrm{M}$ & $0.21-3000 \mu \mathrm{M}$ & $80 \mathrm{nM}$ & [67] \\
\hline
\end{tabular}

NF: Nafion; GR: graphene; PdNPs: palladium nanoparticles; CS: chitosan; NiO: nickel oxide nanoparticles; PLGA: poly lactic-co-glycolic acid; ILs: ionic liquid, 1-butyl-3-methylimidazolium tetrafluoroborate ([BMIM]BF4; BMS: bimodal mesoporous silica; PAM-P123: polyacrylamide-P123; Gel: gelatine; NGC: nanostructured gold colloid; SF: silk fibroin; EDC: 1-ethyl-3-(3-dimethylaminopropyl) carbodiimide; ATP: attapulgite; GNPs: gold colloidal nanoparticles; ${ }^{\mathrm{a}} v s . \mathrm{Ag} / \mathrm{AgCl} ;{ }^{\mathrm{b}} v s . \mathrm{SCE}$. 


\subsection{Stability}

Long-term stability is an important parameter for biosensors. The operational stability of the modified electrode was determined by the $\mathrm{CV}$ method. The cathodic peak current was reduced by less than $5 \%$ after 50 cycles at the scan rate of $0.05 \mathrm{~V} / \mathrm{s}$, while the peak potential remained unchanged. As for the storage stability, the CVs showed minimal change after two weeks of storage in a bottle over the PBS solution at $4{ }^{\circ} \mathrm{C}$. NF may offer a biocompatible micro-environment to confine bio-macromolecules at their ionic cluster region $(30-50 \mathrm{~nm})$, and this view was also consistent with our previous study [45-48]. Moreover, Nafion may be helpful to restrict, confirm and protect Hb/FMWCNTs/Cys/AuNPs system on GC electrodes.

\subsection{Interference Determination}

The degree of interference from interfering substances can be evaluated by the value of the cathodic current ratio which were calculated by reading the cathodic current $\left(\mathrm{I}_{\mathrm{pc} 1}\right)$ of the proposed biosensor in $50 \mathrm{mM}$ PBS ( $\mathrm{pH}$ 7.0) containing $0.10 \mathrm{mM} \mathrm{H}_{2} \mathrm{O}_{2}$ and a $0.20 \mathrm{mM}$ hampering substance, and then, comparing it with the cathodic current $\left(\mathrm{I}_{\mathrm{pc} 0}\right)$ from the proposed biosensor in the same solution containing only $0.10 \mathrm{mM} \mathrm{H}_{2} \mathrm{O}_{2}$. Five interfering substances were tested here and the results are listed in Table 2. It can be observed that none of the tested interferents could cause interference to the determination of $\mathrm{H}_{2} \mathrm{O}_{2}$, which is largely attributed to the low working potential of $-350 \mathrm{mV}$ used in the determination of $\mathrm{H}_{2} \mathrm{O}_{2}$ and the negatively charged $\mathrm{NF}$ protection membrane.

Table 2. Effects of possible interferences on the hydrogen peroxide biosensor.

\begin{tabular}{ccc}
\hline Possible Interferences & $\mathbf{I}_{\mathbf{p c}} / \mathbf{I}_{\mathbf{p c} \mathbf{0}}$ & R.S.D $(\boldsymbol{\%})$ \\
\hline Glucose & $1.04 \pm 0.08$ & 3.2 \\
Adenosine Triphosphate & $1.03 \pm 0.06$ & 3.4 \\
L-Histidine & $1.01 \pm 0.05$ & 2.9 \\
Ascorbic Acid & $0.98 \pm 0.06$ & 3.1 \\
Thiol & $1.00 \pm 0.04$ & 2.5 \\
\hline
\end{tabular}

$\mathbf{I}_{\mathbf{p c 1}}$ : The cathodic current for a mixture of a $0.20 \mathrm{mM}$ interfering substance and $0.10 \mathrm{mM} \mathrm{H}_{2} \mathrm{O}_{2}$; $\mathbf{I}_{\mathbf{p c} 0}$ : The cathodic current for $0.10 \mathrm{mM} \mathrm{H} \mathrm{H}_{2}$ alone in a $50 \mathrm{mM}$ PBS (pH 7.0), at $-350 \mathrm{mV} v$ s. Ag/AgCl. R.S.D: Relative standard deviation, obtained for nine measurements.

\section{Conclusions}

The direct electrochemical properties of immobilized $\mathrm{Hb}$ on a FMWCNTs/Cys/AuNPs-modified glassy carbon electrode were found to be due to the excellent microenvironment provided by NF, AuNPs and FMWCNTs for Hb. The small value of $\mathrm{K}_{\mathrm{m}}{ }^{\text {app }}$, high sensitivity, long-term stability and low detection limit were other characteristics of the biosensor. The modified electrode showed the ability to be used as a third generation biosensor for determination of $\mathrm{H}_{2} \mathrm{O}_{2}$ at ultra-trace levels. Moreover, a redox protein on the functional nano complex modified electrode may be a new useful electrochemical tool for the analysis of relationship between the structure and function of redox proteins, especially for a heme-containing protein. 


\section{Acknowledgments}

The financial supports of Henan University Science Foundation and the Research Council of University of Tehran and the Iran National Science Foundation (INSF) are gratefully acknowledged.

\section{Conflict of Interest}

The authors declare no conflict of interest.

\section{References}

1. Armstrong, F.A.; Hill, H.A.O.; Walton, N.J. Direct electrochemistry of redox proteins. Acc. Chem. Res. 1988, 21, 407-413.

2. Armstrong, F.A.; Wilson, G.S. Recent developments in faradaic bioelectrochemistry. Electrochim. Acta 2000, 45, 2623-2645.

3. Hill, H.A.O. Direct electrochemistry of cytochrome c. Coord. Chem. Rev. 1996, 151, 115-123.

4. Thévenot, D.R.; Toth, K.; Durst, R.A.; Wilson, G.S. Electrochemical biosensors: Recommended definitions and classification. Biosens. Bioelectron. 2001, 16, 121-131.

5. Sun, A.; Sheng, Q.; Zheng, J. A hydrogen peroxide biosensor based on direct electrochemistry of hemoglobin in palladium nanoparticles/graphene-chitosan nanocomposite film. Appl. Biochem. Biotechnol. 2012, 166, 764-773.

6. Salimi, A.; Sharifi, E.; Noorbakhsh, A.; Soltanian, S. Direct voltammetry and electrocatalytic properties of hemoglobin immobilized on a glassy carbon electrode modified with nickel oxide nanoparticles. Electrochem. Commun. 2006, 8, 1499-1508.

7. Li, J.; Tang, J.; Zhou, L.; Han, X.; Liu, H. Direct electrochemistry and electrocatalysis of hemoglobin immobilized on polyacrylamide-P123 film modified glassy carbon electrode. Bioelectrochemistry 2012, 86, 60-66.

8. Yao, H.; Li, N.; Xu, J.Z.; Zhu, J.J. Direct electrochemistry and electrocatalysis of hemoglobin in gelatine film modified glassy carbon electrode. Talanta 2007, 71, 550-554.

9. Guo, H.L.; Liu, D.Y.; Yu, X.D.; Xia, X.H. Direct electrochemistry and electrocatalysis of hemoglobin on nanostructured gold colloid-silk fibroin modified glassy carbon electrode. Sens. Actuators B Chem. 2009, 139, 598-603.

10. Chen, L.; Lu, G. Direct electrochemistry and electrocatalysis of hybrid film assembled by polyelectrolyte-surfactant polymer, carbon nanotubes and hemoglobin. J. Electroanal. Chem. 2006, 597, 51-59.

11. Lee, K.P.; Gopalan, A.I.; Komathi, S. Direct electrochemistry of cytochrome c and biosensing for hydrogen peroxide on polyaniline grafted multi-walled carbon nanotube electrode. Sens. Actuators B Chem. 2009, 141, 518-525.

12. Liu, X.J.; Zhang, W.J.; Huang, Y.X.; Li, G.X. Enhanced electron-transfer reactivity of horseradish peroxidase in phosphatidylcholine films and its catalysis to nitric oxide. J. Biotechnol. 2004, 108, $145-157$. 
13. Liu, Y.; Han, T.; Chen, C.; Bao, N.; Yu, C.M.; Gu, H.Y. A novel platform of hemoglobin on core-shell structurally Fe3O4@Au nanoparticles and its direct electrochemistry. Electrochim. Acta 2011, 56, 3238-3247.

14. Rhieu, S.Y.; Ludwig, D.R.; Siu, V.S.; Palmore, G.T.R. Direct electrochemistry of cytochrome P450 27B1 in surfactant films. Electrochem. Commun. 2009, 11, 1857-1860.

15. Rusling, J.F.; Nassar, A.E.F. Enhanced electron transfer for myoglobin in surfactant films on electrodes. J. Am. Chem. Soc. 1993, 115, 11891-11897.

16. Shang, L.B.; Sun, Z.Y.; Wang, X.W.; Li, G.X. Enhanced peroxidase activity of hemoglobin in a DNA membrane and its application to an unmediated hydrogen peroxide biosensor. Anal. Sci. 2003, 11, 1537-1539.

17. Sun, J.Y.; Huang, K.J.; Zhao, S.F.; Fan, Y.; Wu, Z.W. Direct electrochemistry and electrocatalysis of hemoglobin on chitosan-room temperature ionic liquid- $\mathrm{TiO}_{2}$-graphene nanocomposite film modified electrode. Bioelectrochemistry 2011, 82, 125-130.

18. Xu, J.S.; Zhao, G.C. A third-generation biosensor based on the enzyme-like activity of cytochrome c on a room temperature ionic liquid and gold nanoparticles composite. Int. J. Electrochem. Sci. 2008, 3, 519-527.

19. Yang, J.; Hu, N. Direct electron transfer for hemoglobin in biomembrane-like dimyristoyl phosphatidylcholine films on pyrolytic graphite electrodes. Bioelectrochem. Bioenerg. 1999, 48, 117-127.

20. Yang, N.; Hoffmann, R.; Smirnov, W.; Kriele, A.; Nebel, C.E. Direct electrochemistry of cytochrome c on nanotextured diamond surface. Electrochem. Commun. 2010, 12, 1218-1221.

21. Zhang, Y.; Sun, X.; Jia, N. Direct electrochemistry and electrocatalysis of hemoglobin immobilized into poly (lactic-co-glycolic acid)/room temperature ionic liquid composite film. Sens. Actuators $B$ Chem. 2011, 157, 527-532.

22. Xu, J.; Li, W.; Yin, Q.; Zhong, H.; Zhu, Y.; Jin, L. Direct electron transfer and bioelectrocatalysis of hemoglobin on nano-structural attapulgite clay-modified glassy carbon electrode. J. Colloid Interface Sci. 2007, 315, 170-176.

23. Zhang, R.; Wang, X.; Shiu, K.K. Accelerated direct electrochemistry of hemoglobin based on hemoglobin-carbon nanotube (Hb-CNT) assembly. J. Colloid Interface Sci. 2007, 316, 517-522.

24. Gorton, L.; Lindgren, A.; Larsson, T.; Munteanu, F.D.; Ruzgas, T.; Gazaryan, I. Direct electron transfer between heme-containing enzymes and electrodes as basis for third generation biosensors. Anal. Chim. Acta 1999, 400, 91-108.

25. Olsson, M.G.; Allhorn, M.; Olofsson, T.; AKerstrom, B. Up-regulation of alpha1-microglobulin by hemoglobin and reactive oxygen species in hepatoma and blood cell lines. Free Radic. Biol. Med. 2007, 42, 842-851.

26. Buehler, P.W.; Haney, C.R.; Gulati, A.; Ma, L.; Hsia, C.J.C. Polynitroxyl hemoglobin: A pharmacokinetic study of covalently bound nitroxides to hemoglobin platforms. Free Radic. Biol. Med. 2004, 37, 124-135.

27. Royer, W.E., Jr.; Knapp, J.E.; Strand, K.; Heaslet, H.A. Cooperative hemoglobins: Conserved fold, diverse quaternary assemblies and allosteric mechanisms. Trends Biochem. Sci. 2001, 26, 297-304. 
28. Ding, Y.; Wang, Y.; Li, B.K.; Lei, Y. Electrospun hemoglobin microbelts based biosensor for sensitive detection of hydrogen peroxide and nitrite. Biosens. Bioelectron. 2010, 25, 2009-2015.

29. He, X.Y.; Zhu, L. Direct electrochemistry of hemoglobin in cetylpyridinium bromide film: Redox thermodynamics and electrocatalysis to nitric oxide. Electrochem. Commun. 2006, 8, 615-620.

30. Ferapontova, E.E.; Gorton, L. Direct electrochemistry of heme multicofactor-containing enzymes on alkanethiol-modified gold electrodes. Bioelectrochemistry 2005, 66, 55-63.

31. Parak, F.G.; Nienhaus, G.U. Myoglobin, a paradigm in the study of protein dynamics. Chemphyschem 2002, 3, 249-254.

32. Cao, W.X.; Christian, J.F.; Champion, P.M.; Rosca, F.; Sage, J.T. Water penetration and binding to ferric myoglobin. Biochemistry 2001, 40, 5728-5737.

33. Ajayan, P.M. Nanotubes from carbon. Chem. Rev. 1999, 99, 1787-1800.

34. Ebbesen, T.W.; Ajayan, P.M. Large-Scale synthesis of carbon nanotubes. Nature 1992, 358, 220-222.

35. Iijima, S. Helical microtubules of graphitic carbon. Nature 1991, 354, 56-58.

36. Chen, H.J.; Wang, Y.L.; Wang, Y.Z.H.; Dong, S.H.J.; Wang, E.K. One-Step preparation and characterization of PDDA-protected gold nanoparticles. Polymer 2006, 47, 763-766.

37. Nada, M.D.; David, M.B. Radiolytically induced formation and optical absorption spectra of colloidal silver nanoparticles in supercritical ethane. J. Phys. Chem. B 2001, 105, 954-959.

38. Chen, G.F.; Liang, Z.Q.; Li, G.X. Progress of electrochemical biosensors fabricated with nanomaterials. Acta Biophys. Sin. 2010, 26, 711-725.

39. Scheller, F.W.; Bistolas, N.; Liu, S.Q.; Jänchen, M.; Katterle, M.; Wollenberger, U. Thirty years of haemoglobin electrochemistry. Adv. Colloid Interface Sci. 2005, 116, 111-120.

40. Hong, J.; Yang, W.Y.; Zhao, Y.X.; Xiao, B.L.; Gao, Y.F.; Yang, T.; Ghourchian, H.; Moosavi-Movahedi, Z.; Sheibani, N.; Li, J.G.; et al. Catalase immobilized on a functionalized multi-walled carbon nanotubes-gold nanocomposite as a highly sensitive bio-sensing system for detection of hydrogen peroxide. Electrochim. Acta 2013, 89, 317-325.

41. Yang, W.Y.; Hong, H.; Zhao, Y.X.; Xiao, B.L.; Gao, Y.F.; Yang, T.; Moosavi-Movahedi, A.A.; Ghourchian, H.; Moosavi-Movahedi, Z. Electrochemical study of a nano vesicular artificial peroxidase on a functional nano complex modified glassy carbon electrode. J. New Mat. Electrochem. Syst. 2013, 16, 89-95.

42. Lin, S.Q.; Ju, H.X. Renewable reagentless hydrogen peroxide sensor based on direct electron transfer of horseradish peroxidase immobilized on colloidal gold-modified electrode. Anal. Biochem. 2002, 307, 110-116.

43. Daniel, M.C.; Astruc, D. Gold Nanoparticles: Assembly, supramolecular chemistry, quantum-Size-related properties, and applications toward biology, catalysis, and nanotechnology. Chem. Rev. 2004, 104, 293-346.

44. Xian, Y.; Hu, Y.; Liu, F.; Xian, Y.; Wang, H.; Jin, L. Glucose biosensor based on Au nanoparticles-conductive polyaniline nanocomposite. Biosens. Bioelectron. 2006, 21, 1996-2000.

45. Hong, J.; Ghourchian, H.; Moosavi-Movahedi, A.A. Direct electron transfer of redox proteins on a Nafion-cysteine modified gold electrode. Electrochem. Commun. 2006, 8, 1572-1576. 
46. Hong, J.; Ghourchian, H.; Rezaei-zarchi, S.; Moosavi-Movahedi, A.A.; Ahmadian, S.; Saboury, A.A. Nafion-methylene blue functional memberane and its application in chemical/bio-sensing. Anal. Lett. 2007, 40, 483-496.

47. Hong, J.; Moosavi-Movahedi, A.A.; Ghourchian, H.; Molaei Rad, A. Direct electron transfer of horseradish peroxidase on Nafion-cysteine modified gold electrode. Electrochim. Acta 2007, 52, 6261-6267.

48. Rezaei-Zarchi, S.; Saboury, A.A.; Hong, J.; Norouzi, P.; Moghaddam, A.B.; Ghourchian, H.; Ganjali, M.R.; Moosavi-Movahedi, A.A.; Javed, A.; Mohammadian, A. Electrochemical behavior of redox proteins immobilized on Nafion-riboflavin modified gold electrode. Bull. Korean Chem. Soc. 2007, 28, 2266-2270.

49. Shourian, M.; Ghourchian, H. Biosensing improvement of horseradish peroxidase towards hydrogen peroxide upon modifying the accessible lysines. Sens. Actuators B Chem. 2010, 145, $607-612$.

50. Tian, Y.; Mao, L.; Okajima, T.; Ohsaka, T. A carbon fiber microelectrode-based third-generation biosensor for superoxide anion. Biosens. Bioelectron. 2005, 21, 557-564.

51. Haiss, W.; Thanh, N.T.K.; Aveyard, J.; Fernig, D.G. Determination of size and concentration of gold nanoparticles from UV-vis spectra. Anal. Chem. 2007, 79, 4215-4221.

52. Park, M.J.; Lee, J.K.; Lee, B.S.; Lee, Y.W.; Choi, I.S.; Lee, S.G. Covalent modification of multiwalled carbon nanotubes with imidazolium-based ionic liquids: Effect of anions on solubility. Chem. Mater. 2006, 18, 1546-1551.

53. Shen, J.; Huang, W.; Wu, L.; Hu, Y.; Ye, M. Study on amino-functionalized multiwalled carbon nanotubes. Mater. Sci. Eng. A 2007, 464, 151-156.

54. Wang, J.; Fang, Z.; Gu, A.; Xu, L.; Liu, F. Effect of amino-functionalization of multi-walled carbon nanotubes on the dispersion with epoxy resin matrix. J. Appl. Polym. Sci. 2006, 100, 97-104.

55. Zhang, L.; Zhang, Q.; Li, J. Direct electrochemistry and electrocatalysis of hemoglobin immobilized in bimodal mesoporous silica and chitosan inorganic-organic hybrid film. Electrochem. Commun. 2007, 9, 1530-1535.

56. Laviron, E.J. Adsorption, autoinhibition and autocatalysis in polarography and in linear potential sweep voltammetry. J. Electroanal. Chem. 1974, 52, 355-393.

57. Мa, H.; Hu, N.; Rusling, J.F. Electroactive myoglobin films grown layer-by-layer with poly(styrenesulfonate) on pyrolytic graphite electrodes. Langmuir 2000, 16, 4969-4975.

58. Laviron, E.J. General expression of the linear potential sweep voltammogram in the case of diffusionless electrochemical systems. J. Electroanal. Chem. 1979, 101, 19-28.

59. Rahimi, P.; Rafiee-Pour, H.; Ghourchian, H.; Norouzi, P.; Ganjali, M.R. Ionic-liquid/ NH2-MWCNTs as a highly sensitive nano-composite for catalase direct electrochemistry. Biosen. Bioelectron. 2010, 25, 1301-1306.

60. Wang, S.; Chen, T.; Zhang, Z.; Shen, X.; Lu, Z.; Pang, D.; Wong, K. Direct electrochemistry and electrocatalysis of heme proteins entrapped in agarose hydrogel films in room-temperature ionic liquids. Langmuir 2005, 21, 9260-9266. 
61. Wang, S.; Chen, T.; Zhang, Z.; Pang, D.; Wong, K. Effects of hydrophilic room-temperature ionic liquid 1-butyl-3-methylimidazolium tetrafluoroborate on direct electrochemistry and bioelectrocatalysis of heme proteins entrapped in agarose hydrogel films. Electrochem. Commun. 2007, 9, 1709-1714.

62. Yamazaki, I.; Araiso, T.; Hayashi, Y.; Yamada, H.; Makino, R. Analysis of acid-base properties of peroxidase and myoglobin. Adv. Biophys. 1978, 11, 249-281.

63. Wang, L.; Bo, X.; Bai, J.; Zhu, L.; Guo, L. Gold nanoparticles electrodeposited on ordered mesoporous carbon as an enhanced material for nonenzymatic hydrogen peroxide sensor. Electroanalysis 2010, 22, 2536-2542.

64. Jirkovsky, J.S.; Halasa, M.; Schiffrin, D.J. Kinetics of electrocatalytic reduction of oxygen and hydrogen peroxide on dispersed gold nanoparticles. Phys. Chem. Chem. Phys. 2010, 12, 8042-8052.

65. Molaei Rad, A.; Ghourchian, H.; Moosavi-Movahedi, A.A.; Hong, J.; Nazari, K. Spectrophotometric assay for horseradish peroxidase activity based on pyrocatechol-aniline coupling hydrogen donor. Anal. Biochem. 2007, 362, 38-43.

66. Buck, R.P.; Linder, E. Recommendations for nomenclature of ion selective electrodes. Pure Appl. Chem. 1994, 66, 2527-2536.

67. Chen, S.; Yuan, R.; Chai, Y.; Zhang, L.; Wang, N.; Li, X. Amperometric third-generation hydrogen peroxide biosensor based on the immobilization of hemoglobin on multiwall carbon nanotubes and gold colloidal nanoparticles. Biosens. Bioelectron. 2007, 22, 1268-1274.

68. Shamsipur, M.; Asgari, M.; Maragheh, M.G.; Moosavi-Movahedi, A.A. A novel impedimetric nanobiosensor for low level determination of hydrogen peroxide based on biocatalysis of catalase. Bioelectrochemistry 2012, 83, 31-37.

(C) 2013 by the authors; licensee MDPI, Basel, Switzerland. This article is an open access article distributed under the terms and conditions of the Creative Commons Attribution license (http://creativecommons.org/licenses/by/3.0/). 